\title{
IDENTIFIKASI MISKONSEPSI MENGGUNAKAN THREE-TIER DIAGNOSTIC TEST BERBASIS GOOGLE FORM PADA POKOK BAHASAN POTENSIAL LISTRIK
}

\author{
Eka Maryam \\ eka_maryam@univbinainsan.ac.id \\ Universitas Bina Insan, Lubuklinggau, Indonesia
}

Received: 3 Desember 2020

Revised: 4 Desember 2020

Accepted: 15 Desember 2020

\begin{abstract}
The purpose of this study was to identify misconceptions by using the Google Form-based Three-Tier Diagnostic Test on a potential electrical subject. The type of misconception in question is conceptual misunderstandings or wrong conceptual understanding. This research uses descriptive research with a quantitative approach. This research was conducted in the Computer System Engineering Program of Bina Insan Lubuklinggau University. Data collection techniques using multilevel multiplechoice diagnostic tests, the reason for choosing answers in the form of essays or explaining concepts on the selected answers are then uploaded in jpg or pdf form and lastly the confidence level or Certainty of Response Index (CRI). Data analysis is done by looking for the percentage of misconceptions of each indicator. The results of the study obtained misconception data with an average percentage of $34 \%$ and were in the category of moderate misconceptions. The value of students who understand the concept but are not sure is $1 \%$ and the average value of students who do not understand the concept is 4\%. Overall, the average value of students who understand the concept is greater than in other categories of $61 \%$.
\end{abstract}

\begin{abstract}
Abstrak: Tujuan dari penelitian ini adalah untuk mengidentifikasi miskonsepsi denganmenggunakan Three-Tier Diagnostic Test berbasis Google Form pada pokok bahasan potensial listrik.Jenis miskonsepsi yang dimaksud adalah conceptual misunderstandings atau pemahaman konseptual yang salah. Penelitian ini menggunakan jenis penelitian deskriptif dengan pendekatan kuantitatif. Penelitian ini dilaksanakan di Prodi Rekayasa System Komputer Universitas Bina Insan Lubuklinggau. Teknik pengumpulan data menggunakan tes diagnostik berbentuk pilihan ganda bertingkat, alasan pemilihan jawaban dalam bentuk essay atau menjelaskan konsep pada jawaban yang dipilih kemudian di upload dalam bentuk jpg atau pdf dan terakhir tingkat keyakinan atau Certainty of Response Index (CRI). Analisis data dilakukan dengan mencari persentase miskonsepsi dari masing-masing indikator. Hasil penelitian didapatkan data miskonsepsi dengan persentase rata-rata sebesar $34 \%$ dan berada pada katagori miskonsepsi sedang. Nilai mahasiswa yang paham konsep tetapi kurang yakin sebesar $1 \%$ dan nilai rata-rata mahasiswa yang tidak paham konsep sebesar 4\%. Secara keseluruhan rata-rata nilai mahasiswa yang paham tentang konsep lebih besar dari pada kategori lain yaitu sebesar $61 \%$.
\end{abstract}

Kata kunci: Miskonsepsi, three-tier diagnostic test, google form

\section{PENDAHULUAN}

Pendidikan termasuk aspek penting dalam mencerdaskan masyarakat. Pendidikan dianggap dapat mengubah tingkah laku dan berpikir dalam kehidupan bermasyarakat. Berdasarkan Peraturan Kemendikbud Tahun 2013 No 65, visi dari Pendidikan nasional adalah membuat kondisi pembelajaran yang membuat peserta didik berpartisipasi menggali kemampuan dirinya yang mempunyai pribadi yang baik, kepintaran, akhlak mulia, dan Puplished at https://ojs.stkippgri-lubuklinggau.ac.id/index.php/SJPIF 
tingginya spiritual keagamaan. Peserta didik harus bisa mengggali pengetahuan, sikap, maupun ketrampilan untuk hidup lebih baik pada era globalisasi (Sulistiyono, S, 2020). Pendidikan merupakan suatu proses yang diperlukan untuk mendapatkan keseimbangan dan kesempurnaan dalam perkembangan individu maupun masyarakat. Penekanan pendidikan dibanding dengan pengajaran terletak pada pembentukan kesadaran dan kepribadian individu atau masyarakat di samping transfer ilmu dan keahlian (Zakiya, Z., Amin, A., \& Lovisia, E, 2019).

Fisika merupakan salah satu unsur utama dalam pembangunan dan mewujudkan ilmu Pengetahuan dan Teknologi. Setiap negara berlomba-lomba menemukan produk terutama hasil IPTEK. IPTEK tidak lepas dari salah satu unsur pokok yaitu ilmu fisika, yang bermanfaat bagi perkembangan teknologi. Fisika juga menjadi bagian dari pendidikan bagi semua siswa. Dengan demikian fisika mempunyai peranan yang sangat penting (Ariani, $\mathrm{T}$. (2019). Proses kegiatan belajar mengajar fisika kerap sekali dihadapkan pada sebuah materi yang abstrak. Pelajaran fisika masih terkesan sulit untuk dipahami karena memiliki konsep yang abstrak dan tidak mudah dihubungkan dengan kejadian sehari-hari dalam kehidupan manusia. Hal ini menuntut para pendidik untuk kreatif dalam menciptakan dan mengembangkan media-media pembelajaran agar siswa dapat lebih tertarik dalam mempelajari fisika dan materi yang disampaikan dapat benar-benar dimengerti oleh peserta didik. Faktor penghambat lainnya dalam belajar fisika adalah motivasi siswa tersebut dalam mempelajari materi-materi fisika. Hambatan ini termasuk dalam faktor internal. motivasi merupakan hasrat untuk belajar dari seorang individu. Kurangnya motivasi pada diri siswa menyebabkan seorang siswa tidak sungguh-sungguh atau kurang bersemangat dalam melaksanakan kegiatan sehingga terhambat dalam mencapai tujuan belajar. Apabila siswa tidak termotivasi maka siswa akan malas untuk memperhatikan pelajaran fisika yang disampaikan oleh guru, siswa tidak akan tertarik untuk mengajukan pertanyaan kepada guru terhadap hal-hal yang belum jelas dalam belajar fisika bahkan siswa akan kurang giat belajar agar mendapatkan nilai yang baik dalam mata pelajaran fisika (Maryam, E., \& Fahrudin, A, 2020).

Semestinya kegiatan perkuliahan terjadi interaksi Dosen dan mahasiwa di dalam ruang kelas dalam menjalankan kegiatan belajar mengajar, namun semua itu berubah ketika diawal tahun 2020 tepatnya bulan maret virus covid-19 melanda Indonesia bahkan Dunia. Sistem belajar yang tadinya dilakauakan dengan tatap muka berubah menjadi online atau daring (dalam jaringan). Menurut (Rachmawati. dkk, 2020) pembelajaran online adalah 
sistem belajar yang tersebar tetapi saling terhubung melalui internet dengan memanfaatkan media teknologi untuk melakukan proses kegiatan belajar mengajar. Dalam melakukan pembelajaran fisika secara online tentu lebih susah dari pada pembelajaran secara tatap muka hal ini disebabkan oleh banyak hal, diantaranya dibutuhkannya penguasaan teknologi, belum ketersediaan laboratorium virtual selengkap laboratorium nyata dan lain sebagainnya. Di dalam mempelajari ilmu fisika dibutuhkan penguasaan konsep yang baik dikarnakan ilmu fisika adalah ilmu yang mempelajari tentang sifat dan fenomena alam beserta seluruh interaksi yang terjadi didalamnya yang dimulai dari pengamatan, pengukuran, menganalisis, mengkonsep dan menarik kesimpulan.

Menguasai konsep fisika dengan baik juga menunjukkan bahwa mahasiswa telah memahami materi dengan baik (Sheftyawan, 2018). Akan tetapi dalam pembelajaran fisika sering terjadi miskonsepsi atau pemahaman konsep yang salah sehingga menghambat mahasiswa dalam mencapai tujuan pembelajaran. Menurut (Mosik dan Maulana, 2010) miskonsepsi adalah pola berfikir yang kosisten pada suatu masalah tetapi pola berfikir tersebut salah. Salah satu diantara cara untuk mengetahui miskonsepsi yaitu dengan cara melakukan tes. Tes yang tepat digunakan untuk mengetahui kesalahan konsep (miskonsepsi) dapat menggunakan tes diagnostik.

Menurut (Karim, 2015) diagnosis merupakan suatu proses yang kompleks dalam suatu rangkaian usaha untuk menarik kesimpulan yang didapatkan dari hasil pemerikasaan, perkiraan penyebab dan pengamatan. Sedangkan Three - Tier Diagnostic Test adalah tes diagnostik tingkat tiga dimana tes ini untuk mengukur tingkatan keyakinannya dalam menjawab. Ukuran tingkat keyakinan dari responden dalam menjawab setiap soal atau pertannyaan yang diberikan dianalisis untuk membedakan antara mahasiswa yang mengalami miskonsepsi dan yang tidak mengalami miskonsepsi disebut CRI (Certainty of ResponseIndex). Fungsi utama dari tes diagnostik yaitu mengidentifikasi masalah atau kesulitan yang dialami mahasiswa dan merencanakan tindak lanjut berupa pemecahan masalah yang tepat.

Terdapat berbagai teknik yang dapat digunakan untuk mendeteksi miskonsepsi pada peserta didik. Salah satunya adalah dengan menggunakan Three Tier Diagnostic Test. Penggunaan tes ini diharapkan dapat mengidentifikasi antara peserta didik yang paham konsep, miskonsepsi, dan tidak paham konsep, karena pada tes ini terdapat tiga tingkatan jawaban berupa jawaban pada soal pilihan ganda, alasan terhadap pilihan jawaban, dan Puplished at https://ojs.stkippgri-lubuklinggau.ac.id/index.php/SJPIF 
keyakinan terhadap kedua tingkat jawaban sebelumnya (Jumini, 2017) Penelitian ini dilakukan di tengah pandemi Covid-19 yang sedang terjadi di dunia termasuk Indonesia. Pada saat pandemi terjadi pembatasan aktivitas pada manusia yang disebut physical distancing atau social distancing. Hal tersebut juga berdampak pada dunia pendidikan. Oleh karena itu peneliti tidak dapat melakukan penelitian secara langsung. Pada google terdapat salah satu aplikasi yang dapat digunakan sebagai media dalam pengumpulan data. Google form atau google formulir adalah solusi yang dapat digunakan karena merupakan website yang mampu memberikan tes secara digital. Google form adalah aplikasi dari website google yang berguna dalam membantu mengirim survei, memberikan kuis, atau mengumpulkan informasi secara mudah dan efisien. Aplikasi ini bekerja di dalam penyimpanan google drive Template ini sangat mudah dipahami dan digunakan. Syarat dalam penggunaannya hanya memiliki akun google bagi pembuat atau pengguna formulir (Hasanah, 2020). Penggunaan google form juga dapat terus dilakukan meskipun pandemi sudah berakhir. Hal tersebut seiring dengan perkembangan teknologi digital di era 4.0, teknologi digital memiliki aspek efektivitas, efisiensi, dan daya tarik yang besar.

\section{LANDASAN TEORI}

\section{Miskonsepsi}

Menurut Kose miskonsepsi adalah peserta didik yang mengembangkan pemahaman sendiri tentang suatu konsep tetapi konsep tersebut keliru menurut konsep sebenarnya. Sedangkan menurut Ibrahim, miskonsepsi adalah ide atau pandangan yang keliru mengenai suatu konsep yang dipahami oleh seseorang yang tidak sesuai dengan konsep yang disepakati dan dianggap benar oleh para ahli, biasanya pandangan yang berbeda (salah) bersifat resisten (sulit dirubah) dan persisten (cenderung bertahan). Pandangan ini sulit diubah (Suhermiati, 2015). Sehingga miskonsepsi adalah suatu pemahaman konsep yang salah yang terjadi pada peserta didik, karena tidak sesuai dengan konsep yang sebenarnya yang telah disepakati oleh para ahli. Kesalahan konsep terjadi karena peserta didik mengembangkan pemahaman mereka sendiri tetapi mereka tidak menyadari bahwa konsep yang mereka yakini sebenarnya salah.

Faktor penghambat mahasiswa dalam memahami konsep-konsep fisika salah satunya adalah miskonsepsi. Menurut Verkade dkk., (2017) Kesalah pahaman dalam menghubungkan suatu konsep yaitu antara konsep yang baru dengan konsep yang sudah ada dalam pemiikiran mahasiswa, sehingga mengakibatkan terbentuknya konsep yang salah dan bertentangan 
dengan konsepsi para ahli Fisika. Sedangkan menurut Hashish, A. H., dkk (2020) Miskonsepsi adalah suatu kesalah pahaman konsep yang terjadi pada mahasiswa karena adanya ketidak sesuain pemahaman konsep dengan benar dan dapat menghambat proses pembelajaran. Miskonsepsi juga dapat bersifat menetap saat tidak terbukti salah atau mendapat tantangan konsep lain (Taufiq, 2012). Ada lima bahagian penyebab miskonsepsi fisika yaitu mahasiswa (pengetahuan awal atau prakonsepsi/prior knowledge, pemikiran asosiatif mahasiswa, pemikiran humanistik, reasoning yang tidak lengkap/salah, intuisi yang salah, tahap perkembangan kognitif mahasiswa, kemampuan mahasiswa, dan minat mahasiswa), dosen, bahan ajar atau literatur, konteks dan metode mengajar. Menurut Linawati, dkk (2014) ada lima macam, miskonsepsi fisika yaitu: (a) pemahaman konsep awal (preconceived notions); (b) keyakinan tidak ilmiah (nonscientific beliefs); (c) pemahaman konseptual salah (conceptual misunderstandings); (d) miskonsepsi bahasa daerah (Vernacularmisconceptions); dan (e) miskonsepsi berdasarkan fakta (factual misconceptions).

\section{Three -Tier Diagnostic Test}

Three - Tier Diagnostic Test merupakan tes diagnostik berupa pengembangan dari twotier, dimana pada tes diagnostik tingkat tiga ini peserta didik memberikan tingkat keyakinannya dalam menjawab. Ukuran tingkat keyakinan / kepastian responden dalam menjawab setiap pertanyaan (soal) yang diberikan, yang dikembangkan untuk dapat membedakan antara peserta didik yang mengalami miskonsepsi dan tidak tahu konsep disebut Certainty of Response Index (CRI) (Fitrianingrum, 2017). Menurut (Karim, 2015) diagnosis merupakan suatu proses yang kompleks dalam suatu rangkaian usaha untuk menarik kesimpulan yang didapatkan dari hasil pemerikasaan, perkiraan penyebab dan pengamatan. Sedangkan Three - Tier Diagnostic Test adalah tes diagnostik tingkat tiga dimana tes ini untuk mengukur tingkatan keyakinannya dalam menjawab. Ukuran tingkat keyakinan dari responden dalam menjawab setiap soal atau pertannyaan yang diberikan dianalisis untuk membedakan antara mahasiswa yang mengalami miskonsepsi dan yang tidak mengalami miskonsepsi disebut CRI (Certainty of Response Index). Fungsi utama dari tes diagnostik yaitu mengidentifikasi masalah atau kesulitan yang dialami mahasiswa dan merencanakan tindak lanjut berupa pemecahan masalah yang tepat. Tingkat keyakinan dalam menjawab soal pada teknik CRI digambarkan pada skala 0-5 dengan penjabaran ditunjukkan pada table 1 sebagai berikut. 
Tabel 1. Skala Tingkat Keyakinan berdasarkan Teknik CRI

\begin{tabular}{cll}
\hline Nilai & \multicolumn{1}{c}{ Keterangan } & \multicolumn{1}{c}{ Persentase jawaban } \\
\hline 0 & hanya menebak & Jika menjawab soal, 100\% ditebak \\
1 & lebih banyak menebak & $\begin{array}{l}\text { Jika dalam menjawab soal, persentase unsur } \\
\text { tebakan antara 75-99\% } \\
\text { Jika dalam menjawab soal, persentase unsur } \\
\text { tebakan 50-74\% }\end{array}$ \\
& tidak yakin & $\begin{array}{l}\text { Jika dalam menjawab soal, persentase unsur } \\
\text { tebakan anatara 25-49\% }\end{array}$ \\
& yakin & Jika dalam menjawab soal, persentase unsur \\
4 & tebakan 0-24\% \\
5 & sangat yakin dengan tanpa & $\begin{array}{l}\text { Jika dalam menjawab soal tidak terdapat unsur } \\
\text { tebakan }\end{array}$ \\
\hline
\end{tabular}

Sumber : (Hasan, dkk., 1999)

\section{Google Form}

Google form atau google formulir adalah solusi yang dapat digunakan karena merupakan website yang mampu memberikan tes secara digital. Google form adalah aplikasi dari website google yang berguna dalam membantu mengirim survei, memberikan kuis, atau mengumpulkan informasi secara mudah dan efisien. Aplikasi ini bekerja di dalam penyimpanan google drive. Template ini sangat mudah dipahami dan digunakan.syarat dalam penggunaannya hanya memiliki akun google bagi pembuat atau pengguna formulir (Hasanah, 2020). Google form merupakan salah satu layanan yang diberikan google untuk kelola pendaftaran acara, jejak pendapat, membuat kuis, dan melakukan kuis secara online. Pada google form terdapat tanggapan survei yang diolah menjadi sebuah grafik lingkaran. Google Form merupakan salah satu komponen layanan google docs. Aplikasi ini cocok untuk mahasiswa, guru, dosen, pegawai kantor dan profesional yang senang membuat kuis, form, dan survei online, fitur dari google form dapat dibagi ke orangorang secara terbuka atau khusus kepada pemilik akun google dengan pilihan aksesibilitas, seperti readonly (hanya dapat membaca) atau editable (Hasanah, 2020).

Google Form dapat digunakan dengan syarat harus mempunyai akun universal google yaitu dengan mendaftar di http://account.Google.com/login. Dengan mempunnyai akun tersebut maka kita dapat menggunakan produk Google secara gratis, produk google seperti gmail, gooogle form, google drive, google doc dan lain-lain. Google form adalah aplikasi dari website google yang dapat digunakan untuk membantu mengirim survei, memberikan kuis atau mengumpulkan informasi dengan mudah dan efisien secra online (Iqbal. dkk, 
2018). Hasil dari google form di simpan dalam google drive.Adapun contoh instrument three-tier test berbasis google form yang digunakan dalam penelitian ditunjukkan pada gambar 1 berikut.
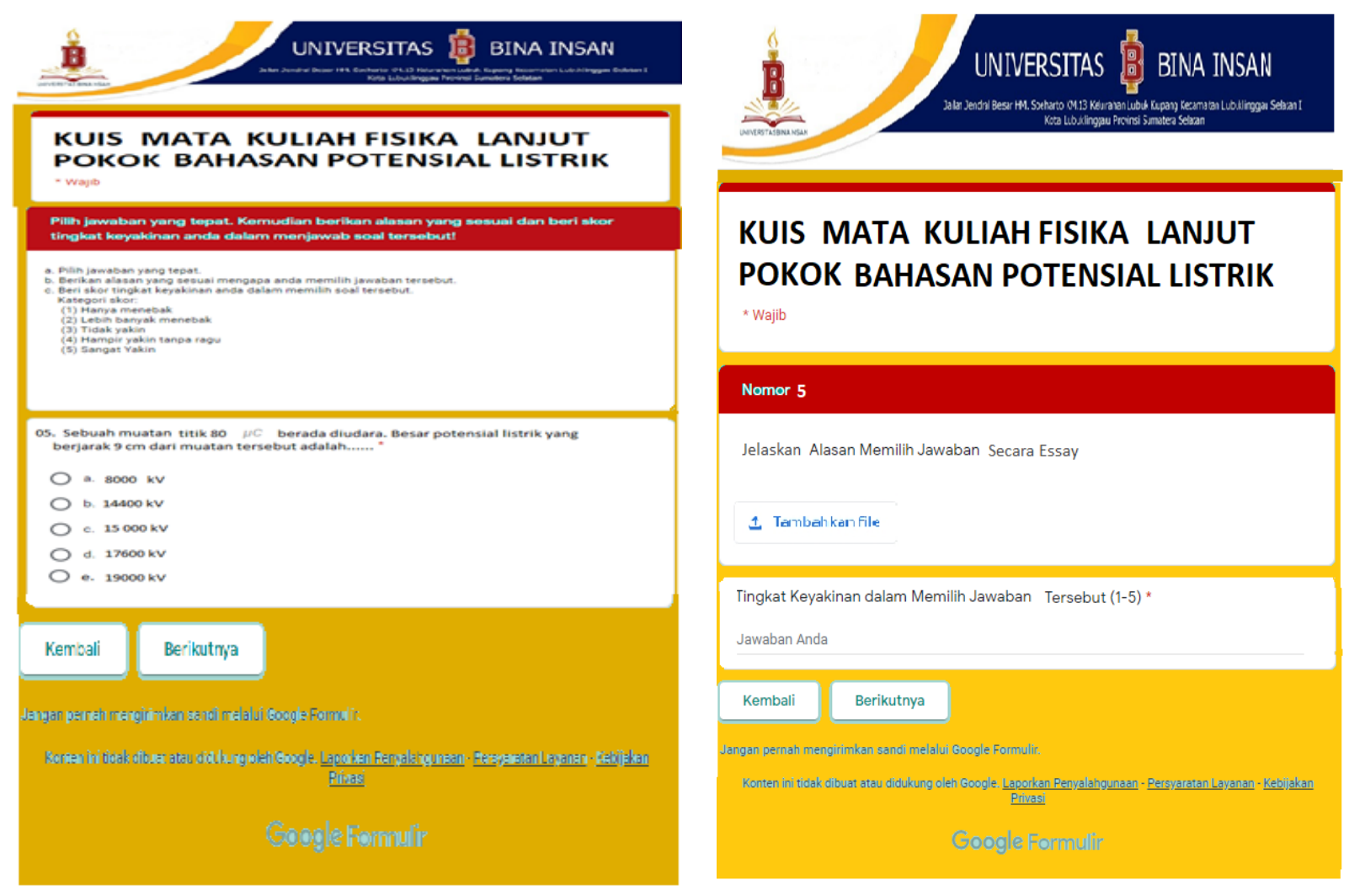

Gambar 1. Contoh bentuk instrument three-tier test berbasis google form (a). Soal tes pilihan ganda, (b). Alasan memilih jawaban atau jawaban secara essay dalam bentuk jpg atau pdf dan tinggkat keyakinan memilih jawaban

\section{METODE PENELITIAN}

Jenis penelitian yang digunakan adalah penelitian deskritif dengan metode kuantitatif. Tujuan penelitian deskriptif adalah untuk mengetahui nilai variabel mandiri (independen) baik satu variabel atau lebih tanpa membandingan atau menghubungkan dengan variabel yang lain, Variabel independen pada penelitian ini yaitu untuk mengetahui hasil dari identifikasi miskonsepsi menggunakan three-tier diagnostic test berbasis google form yang terjadi pada pokok bahasan potensial listrik.

Populasi yang digunakan dalam penelitian ini adalah seluruh mahasiswa prodi rekayasa sitem komputer semester 2 yang mengambil matakuliah fisika lanjut. Sedangkan sampel peneliti diambil menggunakan teknik Sampling Purposive yaitu teknik penentuan sampel dengan pertimbangan tertentu. Sampel penelitian ini diambil di kelas RSK kelas A2 
dengan mempertimbangkan latar belakang daerah asal yang mayoritas dari kota lubuklinggau yang sudah terdapat jaringan internet yang lancer.

Teknik pengumpulan data pada penelitian ini menggunakan Instrumen instrumen tes. Instrumen tes digunakan dengan tujuan untuk mengetahui miskonsepsi yang terjadi pada mahasiswa pada pokok bahasan potensial listrik menggunakan Three - Tier Diagnostic Test berbasis Google Form. Bentuk soal tes berupa pilihan ganda dengan tiga tingkat, tingkat pertama berupa pilihan jawaban, tingkat kedua berupa alasan pemilihan jawaban atau jawaban secara essay yang diuploud dalam bentuk jpg atau pdf, tingkat ketiga berupa tingkat keyakinan dalam memilih jawaban. Sedangkan Teknik analisis data pada penelitian ini berikut:

a. Menganalisis jawaban dari mahasiswa berupa hasil pilihan ganda, alasan pemilihan jawaban dalam bentuk essay atau menjelaskan konsep pada jawaban yang dipilih yang diuploud dalam bentuk jpg atau pdf, dan tingkat keyakinan atas jawaban sesuai dengan kategori tingkat pemahaman pada three-tier diagnostic test.

b. Mengelompokkan jawaban mahasiswa menjadi katagori paham, tidak paham, dan miskonsepsi.

c. Menghitung persentase miskonsepsi yang dialami mahasiswa pada tiap butir soal.

d. Membuat kesimpulan dari data yang diperoleh berupa profil miskonsepsi dan persentase miskonsepsi.

$$
\text { persentase }=\frac{\text { jumlah mahasiswa yng miskonsepsi }}{\text { jumlah } \text { seluruh mahasiswa }} \times 100 \%
$$

Sedangkan uraian penilaian miskonsepsi menggunakan teknik CRI dijabarkan pada table 2 berikut.

Tabel 2. Kriteria Penilaian dengan teknik modifikasi CRI

\begin{tabular}{cccl}
\hline Jawaban & Alasan & Nilai CRI & \multicolumn{1}{c}{ Keterangan } \\
\hline Salah & Salah & $<2,5$ & tidak paham konsep (TPK) \\
Salah & Benar & $<2,5$ & tidak paham konsep (TPK) \\
Salah & Salah & $>2,5$ & Miskonsepsi (M) \\
Salah & Benar & $>2,5$ & Miskonsepsi (M) \\
Benar & Salah & $<2,5$ & paham konsep sebagian (TPK) \\
Benar & Benar & $<2,5$ & paham konsep tetapi tidak yakin (PKKY) \\
Benar & Salah & $>2,5$ & Miskonsepsi (M) \\
Benar & Benar & $>2,5$ & paham konsep dengan benar (PK) \\
\hline
\end{tabular}

Tabel 2 menunjukan kemungkinan kombinasi dari jawaban (benar atau salah) dan nilai CRI (tinggi atau rendah) untuk tiap responden secara individu. Setiap responden dalam satu Puplished at https://ojs.stkippgri-lubuklinggau.ac.id/index.php/SJPIF 
pertanyaan yang diberikan, jawaban benar alasan benar tetapi dengan CRI rendah menandakan tahu konsep tapi tidak yakin (PKKY), dan jawaban benar dengan CRI tinggi menunjukkan penguasaan konsep yang tinggi (PK). Jawaban salah dengan CRI rendah menandakan tidak tahu konsep (TPK), sementara jawaban salah dengan CRI tinggi menandakan terjadinya miskonsepsi (M). sedangkan mahasiswa yang menjawab salah dan tidak yakin atas jawabannya bukan berarti mahasiswa telah mengalami miskonsepsi akan tetapi mengalami kurang paham konsep atau lack of knowledge (Alsagaf, 2019). Adapun rentang ukurang miskonsepsi ditunjukkan pada table 3 berikut.

Tabel 3. Ukuran tingkat miskonsepsi

\begin{tabular}{cc}
\hline Persentase & Kategori \\
\hline $0-30$ & Rendah \\
$31-60$ & Sedang \\
$61-100$ & Tinggi \\
\hline
\end{tabular}

\section{HASIL DAN PEMBAHASAN}

Penelitian ini dilakukan untuk identifikasi miskonsepsi menggunakan three-tier diagnostic test pada materi Potensial Listrik. Ketika mengidentifikasi soal yang telah dikerjakan oleh peserta didik, maka jawaban peserta didik akan dibagi menjadi 4 kategori yaitu Paham Konsep (PK), Miskonsepsi (M), Paham Konsep tetapi Kurang Yakin (PKKY), dan Tidak Paham Konsep (TPK). Pengambilan data dilakukan menggunakan google form hal tersebut bertujuan untuk mempermudah proses identifikasi pada peserta didik pada masa pandemi Covid-19 dikarenakan proses pembelajaran yang dilakukan secara daring. Berdasarkan hasil dari soal tes tersebut diharapkan dapat mengetahui miskonsepsi apa saja yang terjadi pada peserta didik dan berapa persentasenya pada tiap butir soal.

Identifikasi miskonsepsi yang digunakan pada penelitian ini menggunakan salah satu dari tes diagnostik yaitu three-tier diagnostic test. Sebagaimana yang diungkapkan Alsagaf (2019) three-tier diagnostic ini berupa pilihan ganda tiga tingkat dengan tier pertama merupakan soal pilihan ganda biasa, tier kedua berupa alasan dari pilihan jawaban, dan tier ketiga merupakan derajat keyakinan (Certainty of Response Index) untuk meyakinkan respon peserta didik. Certainty of Response Index (CRI) merupakan teknik untuk mengukur tingkat keyakinan dari peserta didik dalam menjawab setiap pertanyaan.

Data hasil penelitian yang didapatkan dari jawaban pilihan ganda, alasan pemilihan jawaban atau jawaban secara essay yang di upload dalam bentuk jpg atau pdf dan tingkat 
keyakinan dari mahasiswa kemudian dianalisis menggunakan three-tier diagnostic test. Hasil tes diagnostik three-tier diagnostic test ditujukkan pada table 4 berikut.

Tabel 4. hasil tes diagnostik three-tier diagnostic test

\begin{tabular}{|c|c|c|c|c|c|c|c|c|c|c|c|c|c|c|c|c|c|c|c|c|}
\hline \multirow{2}{*}{ 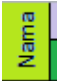 } & \multicolumn{20}{|c|}{ Nomor scal } \\
\hline & 1 & 2 & 3 & 4 & 5 & 6 & 7 & 8 & 9 & 10 & 11 & 12 & 13 & 14 & 15 & 16 & 17 & 18 & 19 & 20 \\
\hline & $B$ S & \begin{tabular}{|c|c|c|c|c|} 
&
\end{tabular} & \begin{tabular}{ll|l|l}
4 & $B$ & $S$ & 4 \\
\end{tabular} & \begin{tabular}{l|l|l|l|l}
4 & $B$ & $S$ & 4 \\
\end{tabular} & \begin{tabular}{ll|l|l|} 
B & S & . \\
\end{tabular} & $\begin{array}{lll}\mathrm{S} & \mathrm{S} & 4 \\
\end{array}$ & \begin{tabular}{ll|l} 
B & 5 & 5 \\
\end{tabular} & \begin{tabular}{l|l|l}
$B$ & $S$ & 4 \\
\end{tabular} & 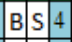 & \begin{tabular}{|l|l|l|} 
& $S$ & 4 \\
\end{tabular} & B S 5 & \begin{tabular}{ll|l} 
B & $S$ & 4 \\
\end{tabular} & \begin{tabular}{|l|l|l}
$B$ & $S$ & 4 \\
\end{tabular} & \begin{tabular}{l|l|l|l|}
4 & $B$ & $B$ & 4 \\
\end{tabular} & \begin{tabular}{|l|l|l|} 
B & $\mathrm{S}$ & 4 \\
\end{tabular} & \begin{tabular}{|l|l|l|}
$B$ & $S$ & 4 \\
\end{tabular} & 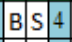 & \begin{tabular}{ll|l|l|}
4 & $B$ & $S$ & 4 \\
\end{tabular} & \begin{tabular}{|l|l|l|}
$B$ & $S$ & 4 \\
\end{tabular} & \begin{tabular}{|l|l|l|l}
4 & B & 4 \\
\end{tabular} \\
\hline R2 & \begin{tabular}{l|l|} 
& $B$ \\
\end{tabular} & \begin{tabular}{|l|l|l|}
$B$ & $B$ & 5
\end{tabular} & \begin{tabular}{l|l|l}
$\mathrm{S}$ & $\mathrm{S}$ & 4
\end{tabular} & \begin{tabular}{l|l|l|l}
4 & $B$ & $B$ & 4
\end{tabular} & \begin{tabular}{|l|l|l|l|}
$B$ & $S$ & 3 \\
\end{tabular} & \begin{tabular}{|l|l|l|}
$S$ & $S$ & 4
\end{tabular} & \begin{tabular}{|l|l|l|}
$B$ & $B$ & 3
\end{tabular} & \begin{tabular}{|l|l|l|}
$B$ & $S$ & 2 \\
\end{tabular} & \begin{tabular}{|l|l|l|l}
$S$ & $S$ & 4
\end{tabular} & \begin{tabular}{|l|l|l|}
$B$ & $S$ & 4 \\
\end{tabular} & \begin{tabular}{|l|l|l|l}
$B$ & $B$
\end{tabular} & \begin{tabular}{|l|l|l|}
$B$ & $S$ & 3
\end{tabular} & \begin{tabular}{|l|l|l|}
$B$ & $B$ & 4 \\
\end{tabular} & 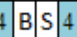 & \begin{tabular}{l|l|l}
$B$ & $B$ & 3
\end{tabular} & \begin{tabular}{|l|l|l|}
$\mathrm{S}$ & $\mathrm{S}$ & 3 \\
\end{tabular} & 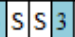 & \begin{tabular}{|l|l|l|l|}
3 & $B$ & $B$ & 4 \\
\end{tabular} & \begin{tabular}{|l|l|l|}
$S$ & $S$ & 4 \\
\end{tabular} & \begin{tabular}{l|l|l|l}
4 & 5 & 5 & 4
\end{tabular} \\
\hline R3 & \begin{tabular}{|l|l|}
$B$ & $S$ \\
\end{tabular} & $B S 5$ & \begin{tabular}{l|l|l|l|}
5 & $\mathrm{~B}$ & 5 \\
\end{tabular} & 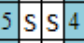 & \begin{tabular}{|l|l|l|}
$\mathrm{S}$ & 3 \\
\end{tabular} & \begin{tabular}{|l|l|l|}
$S$ & 5 \\
\end{tabular} & \begin{tabular}{|l|l|l}
$B$ & 5 \\
\end{tabular} & \begin{tabular}{|l|l|l|l|} 
& S \\
\end{tabular} & \begin{tabular}{|l|l|l|}
$S$ & $S$ \\
\end{tabular} & \begin{tabular}{|l|l|l|}
$B$ & 5 \\
\end{tabular} & \begin{tabular}{|l|l|l}
$B$ & 5 \\
\end{tabular} & \begin{tabular}{|l|l|l}
$B$ & $S$ \\
\end{tabular} & \begin{tabular}{|l|l|l}
$B$ & 5 \\
\end{tabular} & \begin{tabular}{|l|l|l|l|l|l|l}
3 & \\
\end{tabular} & \begin{tabular}{|l|l|l|l|}
$B$ & $S$ & 4 \\
\end{tabular} & \begin{tabular}{|l|l|l|}
$B$ & $S$ \\
\end{tabular} & \begin{tabular}{|l|l|l|}
$B$ & 5 \\
\end{tabular} & \begin{tabular}{|l|l|l|}
5 & \multicolumn{1}{|c|}{} \\
\end{tabular} & \begin{tabular}{|l|l|l|} 
& $S$ & \\
\end{tabular} & $4 \mathrm{~s} s$ \\
\hline & & & $\mathrm{B} B$ & & & \begin{tabular}{|l|l|l|l|l|l|l}
$B$ & $B$ & 3
\end{tabular} & 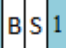 & & \begin{tabular}{|l|l|l|l}
$B$ & $B$ & 4
\end{tabular} & & \begin{tabular}{|l|l|l|l|l|l|l|l}
$B$ & $B$ \\
\end{tabular} & & & \begin{tabular}{l|l|l|l|l}
$B$ & $B$
\end{tabular} & & & & & 3 & \\
\hline R5 & $B$ & \begin{tabular}{|l|l|l|l|}
$B$ & $B$ & 5 \\
\end{tabular} & \begin{tabular}{l|l}
$B$ & 4 \\
\end{tabular} & \begin{tabular}{l|l|l|l|}
4 & $B$ \\
\end{tabular} & \begin{tabular}{|l|l|l} 
& $s$ & 4 \\
\end{tabular} & \begin{tabular}{|l|l|l|}
$B$ & 5 & \\
\end{tabular} & \begin{tabular}{|l|l|l|} 
B & 5 \\
\end{tabular} & \begin{tabular}{|l|l|l|} 
& $B$ & 4 \\
\end{tabular} & $\mathrm{~s} / \mathrm{s}: 3$ & $\mathrm{~B} S \mathrm{~S}$ & \begin{tabular}{l|l|l|l|} 
& $B$ \\
\end{tabular} & \begin{tabular}{l|l|l|} 
& $B$ & 5 \\
\end{tabular} & \begin{tabular}{|l|l|l|l|}
$B$ & $B$ & 4 \\
\end{tabular} & $\begin{array}{l}4 \\
4\end{array}$ & $\mathrm{~B} \mid \mathrm{B} \mathrm{3}^{-1}$ & B 5 S 5 & \begin{tabular}{|l|l|l|}
$B$ & $B$ \\
\end{tabular} & $\begin{array}{l}5 \mathrm{~S} \\
\mathrm{~S}\end{array}$ & $\mathrm{~s} S \mathrm{~s}$ & 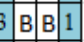 \\
\hline R6 & \begin{tabular}{l|l|}
$B$ & $B$ \\
\end{tabular} & \begin{tabular}{|l|l|l|}
$\mathrm{B}$ & $\mathrm{B}$ & 5 \\
\end{tabular} & \begin{tabular}{|l|l|l}
$S$ & $S$ & 4 \\
\end{tabular} & \begin{tabular}{l|l|l|l|l|}
4 & $\mathrm{~B}$ & $\mathrm{~B}$ & 5
\end{tabular} & \begin{tabular}{|l|l|l}
$S$ & $S$ & 4 \\
\end{tabular} & \begin{tabular}{|l|l|l|}
$\mathrm{B}$ & $\mathrm{B}$ & 4 \\
\end{tabular} & \begin{tabular}{|l|l|l|}
$B$ & $B$ & 4 \\
\end{tabular} & \begin{tabular}{|l|l|l|}
$B$ & $B$ & 4 \\
\end{tabular} & \begin{tabular}{|l|l|l|}
$B$ & $B$ & 4 \\
\end{tabular} & \begin{tabular}{|l|l|l|}
$B$ & $B$ \\
\end{tabular} & \begin{tabular}{|l|l|l|}
$S$ & $s$ \\
\end{tabular} & \begin{tabular}{|l|l|l|}
$B$ & $B$ & 4 \\
\end{tabular} & \begin{tabular}{|l|l|l|}
$B$ & $B$ & 5 \\
\end{tabular} & \begin{tabular}{l|l|l|l|l}
5 & $s$ & 3
\end{tabular} & \begin{tabular}{|l|l|l|}
$B$ & $B$ & 5
\end{tabular} & \begin{tabular}{|l|l|l|}
$B$ & $B$ & 4 \\
\end{tabular} & \begin{tabular}{|l|l|l|}
$B$ & $B$ \\
\end{tabular} & \begin{tabular}{l|l|l|l|}
5 & $B$ & $B$ & 3 \\
\end{tabular} & \begin{tabular}{|l|l|}
$s$ & $s$ \\
\end{tabular} & \begin{tabular}{l|l|l|}
3 & $B$ \\
\end{tabular} \\
\hline R7 & \begin{tabular}{|l|l|}
$B$ & $B$ \\
\end{tabular} & \begin{tabular}{|l|l|l|}
$B$ & $B$ \\
\end{tabular} & \begin{tabular}{|l|l|l}
$B$ & $B$ & 4 \\
\end{tabular} & \begin{tabular}{l|l|l|l|l|l|}
4 & $B$ & $B$ \\
\end{tabular} & \begin{tabular}{|l|l|l}
$S$ & 5 \\
\end{tabular} & \begin{tabular}{|l|l|l|}
$B$ & $B$ & 5 \\
\end{tabular} & \begin{tabular}{|l|l|l}
$B$ & $B$ & 5 \\
\end{tabular} & \begin{tabular}{|l|l|l|l|l|} 
& $B$ & & 5 \\
\end{tabular} & \begin{tabular}{|l|l|l|}
$B$ & $B$ & 5 \\
\end{tabular} & \begin{tabular}{|l|l|l}
$B$ & $B$ & 5 \\
\end{tabular} & \begin{tabular}{|l|l|l|}
$B$ & $B$ \\
\end{tabular} & \begin{tabular}{|l|l|l}
$B$ & $B$ & 4 \\
\end{tabular} & \begin{tabular}{|l|l|l}
$B$ & $B$ & 4 \\
\end{tabular} & $4 \mathrm{~S} S \mathrm{~S}: 4$ & \begin{tabular}{|l|l|l|l|}
$B$ & B & 4 \\
\end{tabular} & \begin{tabular}{|c|c|c|}
$B$ & $B$ & 4 \\
\end{tabular} & \begin{tabular}{|c|c|c|c|}
$B$ & $B$ & 4 \\
\end{tabular} & \begin{tabular}{l|l|l|l|l} 
& 5 & 4 \\
\end{tabular} & \begin{tabular}{|l|l|l|} 
& $\mathrm{S}$ & 3 \\
\end{tabular} & \begin{tabular}{|l|l|l|} 
& $B$ & $B$ \\
\end{tabular} \\
\hline R8 & \begin{tabular}{l|l} 
& $B$ \\
\end{tabular} & \begin{tabular}{|l|l|l|} 
& $S$ & 2 \\
\end{tabular} & \begin{tabular}{|l|l|l}
$B$ & $B$ & 4
\end{tabular} & \begin{tabular}{l|l|l|l|}
4 & $B$ & $B$ & 5 \\
\end{tabular} & \begin{tabular}{|l|l|l|}
$B$ & $B$ & 5 \\
\end{tabular} & \begin{tabular}{|l|l|l|}
$B$ & $B$ & 5 \\
\end{tabular} & \begin{tabular}{|l|l|l|}
$B$ & $B$ & 5 \\
\end{tabular} & 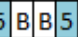 & \begin{tabular}{|l|l|l|}
$B$ & $B$ & 4 \\
\end{tabular} & \begin{tabular}{|l|l|l|}
$B$ & $B$ & 5 \\
\end{tabular} & \begin{tabular}{|l|l|l|}
$B$ & $B$ & 5 \\
\end{tabular} & \begin{tabular}{|l|l|l|}
$B$ & $B$ & 5 \\
\end{tabular} & \begin{tabular}{|l|l|l|}
$B$ & $B$ & 5 \\
\end{tabular} & \begin{tabular}{l|l|l}
5 & 5 & 5
\end{tabular} & \begin{tabular}{|l|l|l|}
$B$ & $B$ & 5 \\
\end{tabular} & \begin{tabular}{|l|l|l|}
$B$ & $B$ & 5 \\
\end{tabular} & \begin{tabular}{|l|l|l|}
$B$ & $B$ & 5 \\
\end{tabular} & \begin{tabular}{|l|l|l|}
5 & $B$ & $B$ \\
\end{tabular} & \begin{tabular}{|l|l|l|}
$B$ & $B$ & 5
\end{tabular} & \begin{tabular}{l|l}
$\mathrm{S}$ & 5 \\
\end{tabular} \\
\hline R9 & \begin{tabular}{|l|l|} 
& $B$ \\
\end{tabular} & \begin{tabular}{|c|c|c|}
$B$ & $S$
\end{tabular} & \begin{tabular}{l|l|l|l|l}
4 & 5 \\
\end{tabular} & \begin{tabular}{l|l|l|l|l|}
5 & $B$ & $B$ \\
\end{tabular} & \begin{tabular}{|l|l|l|}
$B$ & 5 \\
\end{tabular} & \begin{tabular}{|l|l|l|}
$S$ & $S$ & 4 \\
\end{tabular} & \begin{tabular}{|l|l|l}
$B$ & $B$ & 4 \\
\end{tabular} & \begin{tabular}{|l|l|l|l|l|l|l|} 
& $B$ & \\
\end{tabular} & \begin{tabular}{|l|l|l|}
$B$ & $S$ & 3 \\
\end{tabular} & \begin{tabular}{|l|l|l}
$B$ & $B$ & 5 \\
\end{tabular} & \begin{tabular}{|l|l|l|l|}
$B$ & $B$ & \\
\end{tabular} & \begin{tabular}{l|l}
$S$ & $S$ \\
\end{tabular} & \begin{tabular}{|l|l|l}
$B$ & $B$ & 5 \\
\end{tabular} & 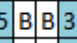 & \begin{tabular}{|l|l|l|l|}
$B$ & $B$ & 4 \\
\end{tabular} & \begin{tabular}{|l|l|l|l|}
$B$ & $B$ & 4 \\
\end{tabular} & \begin{tabular}{|l|l|l|l|l|l|l|l|} 
& \\
\end{tabular} & \begin{tabular}{|l|l|l|l|}
5 & $\mathrm{~B}$ & $\mathrm{~B}$ \\
\end{tabular} & $\begin{array}{lll} & S & 3 \\
\end{array}$ & \begin{tabular}{|l|l|l|l|l}
3 & $B$ & $B$ & 4 \\
\end{tabular} \\
\hline & $B$ B & & \begin{tabular}{l|l|l|l|l}
5 & 2 \\
\end{tabular} & \begin{tabular}{ll|l}
2 & $\mathrm{~S}$ & $\mathrm{~S}$ \\
\end{tabular} & & & & & & & & & & \begin{tabular}{|l|l|l|l|}
5 & B & 5 & 4 \\
\end{tabular} & & \begin{tabular}{|l|l|l|l|}
$B$ & $B$ & 4 \\
\end{tabular} & \begin{tabular}{|l|l|l|}
$B$ & $B$ & 5 \\
\end{tabular} & 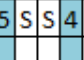 & S S 5 & \begin{tabular}{l|l|l}
5 & $B$ & $B$ \\
\end{tabular} \\
\hline
\end{tabular}

Keterangan

$$
\begin{aligned}
& \text { B }=\text { Benar } \\
& \text { S }=\text { Salah } \\
& 1 \text { = Hanya Menebak } \\
& 2 \text { = Lebih banyak menebak } \\
& 3 \text { = Tidak yakin } \\
& 4=\text { Hampir yakin tanpa ragu } \\
& 5=\text { Sangat yakin }
\end{aligned}
$$

\begin{tabular}{|c|c|c|c|c|c|c|c|c|c|c|c|c|c|c|c|c|c|c|c|c|}
\hline \multirow[t]{2}{*}{ NAMA } & \multicolumn{20}{|c|}{ Nomor Soal } \\
\hline & 1 & 2 & 3 & 4 & 5 & 6 & 7 & 8 & 9 & $\begin{array}{l}1 \\
\mathbf{0}\end{array}$ & $\begin{array}{l}1 \\
1\end{array}$ & 12 & 13 & $\begin{array}{l}1 \\
4\end{array}$ & $\begin{array}{l}1 \\
5\end{array}$ & 16 & $\begin{array}{l}1 \\
7\end{array}$ & $\begin{array}{l}1 \\
8\end{array}$ & 19 & 20 \\
\hline $\begin{array}{l}\text { Responde } \\
\text { n } 1\end{array}$ & M & M & M & M & M & M & M & M & M & M & M & M & M & M & M & M & $M$ & $\mathrm{M}$ & M & M \\
\hline $\begin{array}{l}\text { Responde } \\
\text { n } 2\end{array}$ & PK & PK & $\begin{array}{l}\mathrm{P} \\
\mathrm{K}\end{array}$ & $\mathrm{M}$ & PK & $\begin{array}{l}\mathrm{P} \\
\mathrm{K}\end{array}$ & PK & PK & PK & PK & $\mathrm{M}$ & $\mathrm{PK}$ & PK & $\mathrm{M}$ & $\mathrm{PK}$ & PK & PK & PK & PK & PK \\
\hline $\begin{array}{l}\text { Responde } \\
\text { n } 3\end{array}$ & PK & PK & $\begin{array}{l}\mathrm{P} \\
\mathrm{K}\end{array}$ & $\begin{array}{l}\mathrm{P} \\
\mathrm{K}\end{array}$ & PK & $\begin{array}{l}\mathrm{P} \\
\mathrm{K}\end{array}$ & $\mathrm{PK}$ & PK & PK & PK & $\mathrm{PK}$ & PK & PK & PK & $\mathrm{PK}$ & PK & PK & $\mathrm{PK}$ & PK & PK \\
\hline $\begin{array}{l}\text { Responde } \\
\text { n } 4\end{array}$ & PK & $\mathrm{PK}$ & $\begin{array}{l}\mathrm{P} \\
\mathrm{K}\end{array}$ & $\begin{array}{l}\mathrm{P} \\
\mathrm{K}\end{array}$ & PK & M & $\mathrm{PK}$ & PK & $\mathrm{M}$ & PK & PK & PK & $\mathrm{PK}$ & $\begin{array}{l}\mathrm{PK} \\
\mathrm{K} \\
\mathrm{Y}\end{array}$ & $\mathrm{PK}$ & PK & $\mathrm{PK}$ & $\mathrm{PK}$ & PK & TPK \\
\hline $\begin{array}{l}\text { Responde } \\
\text { n } 5\end{array}$ & PK & $\begin{array}{l}\mathrm{TP} \\
\mathrm{K}\end{array}$ & $\begin{array}{l}\mathrm{P} \\
\mathrm{K}\end{array}$ & $\begin{array}{l}\mathrm{P} \\
\mathrm{K}\end{array}$ & PK & $\begin{array}{l}\mathrm{P} \\
\mathrm{K}\end{array}$ & $\mathrm{PK}$ & PK & PK & PK & PK & PK & PK & PK & $\mathrm{PK}$ & PK & $\mathrm{PK}$ & PK & TPK & M \\
\hline $\begin{array}{l}\text { Responde } \\
\text { n } 6\end{array}$ & PK & PK & $\begin{array}{l}\mathrm{P} \\
\mathrm{K}\end{array}$ & M & M & $\begin{array}{l}\mathrm{P} \\
\mathrm{K}\end{array}$ & PK & PK & M & PK & PK & PK & PK & M & $\mathrm{PK}$ & PK & $\mathrm{PK}$ & PK & PK & M \\
\hline
\end{tabular}

Setelah dilakukan analisis dengan three-tier diagnostic test kemudian data yang didapat dilakukan analisis sesuai CRI (Certainty of Response Index) untuk mempermudah membedakan mahasiswa yang Paham Konsep (PK), Miskonsepsi (M), Paham Konsep tetapi Kurang Yakin (PKKY) dan Tidak Paham Konsep (TPK). Adapun hasil analisis menggunakan metode CRI (Certainty of Response Index) ditunjukkan pada table 5 berikut.

Tabel 5. Hasil analisis menggunakan metode CRI (Certainty of Response Index)

Puplished at https://ojs.stkippgri-lubuklinggau.ac.id/index.php/SJPIF 


\begin{tabular}{|c|c|c|c|c|c|c|c|c|c|c|c|c|c|c|c|c|c|c|c|c|}
\hline $\begin{array}{l}\text { Responde } \\
\text { n } 7 \\
\end{array}$ & PK & PK & M & $\mathrm{M}$ & PK & $\begin{array}{l}\mathrm{P} \\
\mathrm{K} \\
\end{array}$ & $\begin{array}{l}\text { TP } \\
\mathrm{K}\end{array}$ & PK & $\mathrm{M}$ & $\mathrm{PK}$ & $\mathrm{PK}$ & PK & PK & $\mathrm{M}$ & PK & $\mathrm{M}$ & $\mathrm{M}$ & $\mathrm{M}$ & $M$ & PK \\
\hline $\begin{array}{l}\text { Responde } \\
\text { n } 8\end{array}$ & $\mathrm{M}$ & $\mathrm{M}$ & $\mathrm{M}$ & $\mathbf{M}$ & $\mathrm{M}$ & $\mathrm{M}$ & $\mathrm{M}$ & $\mathrm{M}$ & $\mathrm{M}$ & $\mathrm{M}$ & $\mathrm{M}$ & $\mathrm{M}$ & $\mathrm{M}$ & $\mathrm{M}$ & $\mathrm{M}$ & $\mathrm{M}$ & $\mathrm{M}$ & $\mathrm{M}$ & $\mathrm{M}$ & $\mathrm{M}$ \\
\hline $\begin{array}{l}\text { Responde } \\
\text { n } 9\end{array}$ & $\mathrm{PK}$ & PK & M & $\mathrm{K}$ & M & M & PK & $\begin{array}{l}\mathrm{TP} \\
\mathrm{K}\end{array}$ & $\mathrm{M}$ & $\mathrm{M}$ & PK & $\mathrm{M}$ & $\mathrm{PK}$ & PK & $\mathrm{PK}$ & $\mathrm{M}$ & $\mathrm{M}$ & $\mathrm{M}$ & PK & PK \\
\hline $\begin{array}{l}\text { Responde } \\
\text { n } 10\end{array}$ & $\mathrm{PK}$ & $\mathrm{M}$ & $\mathrm{M}$ & $\mathrm{M}$ & $\mathrm{M}$ & $\mathrm{M}$ & $\mathrm{M}$ & $\mathrm{M}$ & $\begin{array}{l}\text { TP } \\
\mathrm{K}\end{array}$ & $\mathrm{M}$ & $\mathrm{M}$ & $M$ & $\mathrm{M}$ & $M$ & $\mathrm{M}$ & $\mathrm{M}$ & $M$ & $\mathrm{M}$ & $\mathrm{M}$ & $\mathrm{M}$ \\
\hline $\begin{array}{l}\text { Responde } \\
\text { n } 11\end{array}$ & PK & PK & $\mathrm{PK}$ & $\mathrm{M}$ & PK & PK & $\begin{array}{l}\text { TP } \\
\mathrm{K}\end{array}$ & $\mathrm{PK}$ & PK & PK & PK & $\mathrm{M}$ & $\mathrm{M}$ & PK & PK & PK & $M$ & $\mathrm{M}$ & PK & PK \\
\hline $\begin{array}{l}\text { Responde } \\
\text { n } 12\end{array}$ & $\mathrm{PK}$ & PK & $\mathrm{M}$ & $\begin{array}{l}\mathrm{P} \\
\mathrm{K}\end{array}$ & $\mathrm{M}$ & $\mathrm{M}$ & $\mathrm{M}$ & PK & PK & $\mathrm{M}$ & PK & PK & PK & M & PK & $\mathrm{M}$ & $\mathrm{M}$ & $\mathrm{M}$ & TPK & TPK \\
\hline $\begin{array}{l}\text { Responde } \\
\text { n } 13\end{array}$ & $\mathrm{PK}$ & PK & $\mathrm{M}$ & $\begin{array}{l}\mathrm{P} \\
\mathrm{K}\end{array}$ & $\mathrm{M}$ & PK & PK & PK & PK & PK & $\begin{array}{l}\mathrm{PK} \\
\mathrm{K} \\
\mathrm{Y}\end{array}$ & $\mathrm{PK}$ & PK & $\mathrm{M}$ & PK & PK & $\mathrm{M}$ & $\mathrm{M}$ & PK & PK \\
\hline $\begin{array}{l}\text { Respo } \\
\text { n } 14\end{array}$ & PK & PK & PK & $\begin{array}{l}\mathrm{P} \\
\mathrm{K}\end{array}$ & $\mathrm{M}$ & PK & PK & PK & PK & PK & PK & PK & PK & $\mathrm{M}$ & PK & PK & $\mathrm{M}$ & $\mathrm{M}$ & $\mathrm{M}$ & PK \\
\hline $\begin{array}{l}\text { Responde } \\
\text { n } 15\end{array}$ & $\mathrm{PK}$ & $\begin{array}{l}\text { TP } \\
\text { K }\end{array}$ & PK & $\begin{array}{l}\mathrm{P} \\
\mathrm{K}\end{array}$ & PK & PK & PK & PK & PK & PK & $\mathrm{PK}$ & PK & PK & $\begin{array}{l}\text { TP } \\
\text { K }\end{array}$ & PK & PK & $\mathrm{PK}$ & $\mathrm{PK}$ & PK & $\mathrm{PK}$ \\
\hline $\begin{array}{l}\text { Responde } \\
\text { n } 16\end{array}$ & $\mathrm{PK}$ & $\mathrm{M}$ & $\mathrm{M}$ & $\begin{array}{l}\mathrm{P} \\
\mathrm{K}\end{array}$ & $\mathrm{PK}$ & $\mathrm{M}$ & $\mathrm{M}$ & $\mathrm{PK}$ & $\mathrm{M}$ & $\mathrm{PK}$ & PK & $\mathrm{M}$ & PK & PK & PK & PK & $\mathrm{M}$ & $\mathrm{M}$ & $\mathrm{M}$ & PK \\
\hline $\begin{array}{l}\text { Responde } \\
\text { n } 17\end{array}$ & PK & PK & $\begin{array}{l}\text { TP } \\
\mathrm{K}\end{array}$ & $\mathrm{M}$ & $\mathrm{PK}$ & $\begin{array}{l}\mathrm{PK} \\
\end{array}$ & PK & PK & PK & PK & $\mathrm{M}$ & $M$ & $\mathrm{M}$ & $\mathrm{PK}$ & PK & PK & $\mathrm{M}$ & $\mathrm{M}$ & PK & PK \\
\hline $\begin{array}{l}\text { Responde } \\
\text { n } 18\end{array}$ & $\mathrm{PK}$ & $\mathrm{M}$ & $\mathrm{M}$ & $\begin{array}{l}\mathrm{P} \\
\mathrm{K}\end{array}$ & $\begin{array}{l}\mathrm{PK} \\
\mathrm{KY}\end{array}$ & PK & PK & PK & PK & PK & $\mathrm{PK}$ & $\mathrm{M}$ & PK & PK & PK & PK & $\begin{array}{l}\text { TP } \\
\mathrm{K}\end{array}$ & $\begin{array}{l}\mathrm{TP} \\
\mathrm{K}\end{array}$ & $\begin{array}{l}\text { PK } \\
\text { KY }\end{array}$ & $\mathrm{M}$ \\
\hline $\begin{array}{l}\text { Responde } \\
\text { n } 19\end{array}$ & $\mathrm{PK}$ & PK & $\mathrm{M}$ & $\begin{array}{l}\mathrm{P} \\
\mathrm{K}\end{array}$ & PK & PK & PK & PK & PK & $\mathrm{PK}$ & $\mathrm{PK}$ & $\begin{array}{l}\mathrm{TP} \\
\mathrm{K}\end{array}$ & $\mathrm{M}$ & $\mathrm{PK}$ & PK & PK & M & $\mathrm{M}$ & PK & PK \\
\hline $\begin{array}{l}\text { Responde } \\
\text { n } 20\end{array}$ & $\mathrm{PK}$ & PK & $\mathrm{PK}$ & $\mathrm{P}$ & $\mathrm{M}$ & PK & PK & PK & PK & $\mathrm{M}$ & $\mathrm{PK}$ & PK & PK & PK & PK & PK & $\mathrm{M}$ & $\mathrm{M}$ & TPK & PK \\
\hline PK (\%) & 90 & 65 & 45 & $\begin{array}{l}6 \\
0 \\
\end{array}$ & 50 & 65 & 65 & 85 & 60 & 70 & 70 & 55 & 70 & 50 & 85 & 70 & 30 & 30 & 50 & 55 \\
\hline M (\%) & 10 & 25 & 50 & $\begin{array}{l}4 \\
0\end{array}$ & 45 & 35 & 25 & 10 & 35 & 30 & 25 & 40 & 30 & 40 & 15 & 30 & 65 & 65 & 30 & 35 \\
\hline $\begin{array}{l}\text { PKKY } \\
(\%)\end{array}$ & 0 & 0 & 0 & 0 & 5 & 0 & 0 & 0 & 0 & 0 & 5 & 0 & 0 & 5 & 0 & 0 & 0 & 0 & 5 & 0 \\
\hline TPK (\%) & 0 & 10 & 5 & 0 & 0 & 0 & 10 & 5 & 5 & 0 & 0 & 5 & 0 & 5 & 0 & 0 & 5 & 5 & 15 & 10 \\
\hline
\end{tabular}

Dari analisis analisis menggunakan metode CRI (Certainty of Response Index) kemudian dilakukan persentase tiap indicator untuk mengetahui tingkat miskonsepsinya. Hasil persentase miskonsepsi dari tiap indikator soal ditunjukan pada table 4 .

Tabel 4. Rata-rata persentase miskonsepsi dari tiap indikator soal

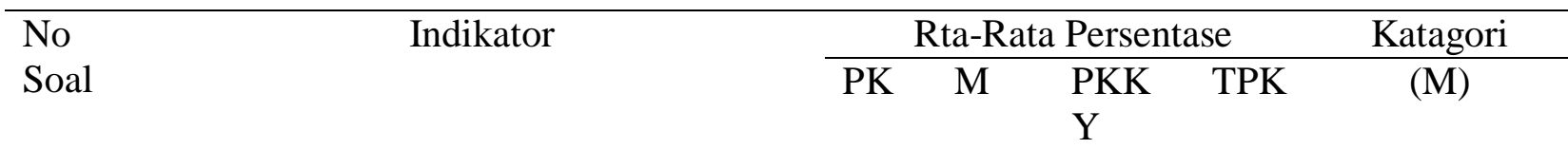

1-2 Menjelaskan beda potensial, dan potensial listrik, dan usaha dalam medan listrik dan bidang ekipotensial.

$77,5 \quad 17,5 \quad 0 \quad 5 \quad$ Rendah

3-4 Menjabarkan gradient potensial untuk menjelaskan hubungan medan dan potensial listrik

$52,5 \quad 45 \quad 0 \quad 2,5 \quad$ Sedang

Puplished at https://ojs.stkippgri-lubuklinggau.ac.id/index.php/SJPIF 


\begin{tabular}{|c|c|c|c|c|c|c|}
\hline $5-6$ & $\begin{array}{l}\text { Menjelaskan konsep dan menjabarkan } \\
\text { persamaan potensial listrik sebuah } \\
\text { muatan titik }\end{array}$ & 57,5 & 40 & 2,5 & 0 & Sedang \\
\hline $7-8$ & $\begin{array}{l}\text { Menjelaskan konsep dan menjabarkan } \\
\text { persamaan potensial listrik sebuah } \\
\text { dipole listrik }\end{array}$ & 75 & 17,5 & 0 & 7,5 & Rendah \\
\hline $9-10$ & $\begin{array}{l}\text { Menjabarkan energi potensial listrik dari } \\
\text { system muatan titik }\end{array}$ & 65 & 32,5 & 0 & 2,5 & Sedang \\
\hline $11-12$ & $\begin{array}{l}\text { Menjabarkan potensial listrik dari } \\
\text { konduktor yang dimuati. }\end{array}$ & 62,5 & 32,5 & 2,5 & 2,5 & Sedang \\
\hline $13-14$ & $\begin{array}{l}\text { Menjelaskan konsep dan marumuskan } \\
\text { kapasitansi }\end{array}$ & 60 & 35 & 2,5 & 2,5 & Sedang \\
\hline $15-16$ & Menjelaskan dielektrikum & 77,5 & 22,5 & 0 & 0 & Rendah \\
\hline $17-18$ & $\begin{array}{l}\text { Menjelaskan energi yang } \\
\text { tersimpan dalam medan } \\
\text { listrik. } \\
\text { Menielaskan nrinsin keria tabung sinar }\end{array}$ & 30 & 65 & 0 & 5 & Tinggi \\
\hline & katoda $\quad$ Rata-rata & $\begin{array}{c}52,5 \\
61\end{array}$ & $\begin{array}{c}32,5 \\
34\end{array}$ & $\begin{array}{c}2,5 \\
1\end{array}$ & $\begin{array}{c}12,5 \\
4\end{array}$ & Sedang \\
\hline
\end{tabular}

Keterangan:

$\begin{array}{ll}\text { PK } & \text { : Paham Konsep } \\ \text { M } & \text { : Miskonsepsi } \\ \text { PKKY } & \text { : Paham Konsep tetapi Kurang Yakin } \\ \text { TPK } & \text { : Tidak Paham Konsep }\end{array}$

Dari tabel diatas diketahui bahwa mahasiswa mampu menjawab soal atau memahami konsep dengan baik (PK) paling tinggi pada dua indikator yaitu indikator menjelaskan beda potensial, potensial listrik, usaha dalam medan listrik serta bidang ekipotensial dan pada indikator menjelaskan dielektrikum dengan persentase $77,5 \%$ sedangkan mahasiswa yang mengalami miskonsepsi (M) paling tinggi pada indikator menjelaskan energy yang tersimpan dalam medan magnet dengan persentase $65 \%$. Sedangkan indikator soal yang paling tinggi membuat mahasiswa tidak paham konsep (TPK) yaitu pada indikator menjelaskan konsep dan menjabarkan persamaan potensial listrik sebuah dipole listrik.

Adapun hasil rata-rata rata-rata mahasiswa yang tidak paham konsep (TPK) sebesar 4\% dan $1 \%$ mahasiwa yang paham konsep tapi kurang yakin (PKKY) dapat simpulkan berada pada katagori rendah. Sedangkan hasil rata-rata mahasiswa mengalami miskonsepsi (M) sebesar $34 \%$ atau berada pada ukuran tingkat miskonsepsi sedang (31- $60=$ sedang) akan tetapi hasil rata-rata mahasiswa yang paham konsep (PK) lebih besar yaitu $61 \%$ atau pada katagori tinggi.

Hasil penelitian ini mendukung penelitian terdahulu yang dilakukan oleh Jumini, dkk.(2017) dengan judul Identifikasi Miskonsepsi Fisika Menggunakan Three Tier Puplished at https://ojs.stkippgri-lubuklinggau.ac.id/index.php/SJPIF 
Diagnostic Test pada Pokok Bahasan Kinematika Gerak bahwa three-tier diagnostic test adalah salah satu tes pilihan ganda yang disertai dengan alasan dan keyakinan jawaban. Tes three-tier dapat membedakan kurangnya pengetahuan peserta didik dari miskonsepsi dengan adanya tingkatan ketiga yang menilai seberapa yakin peserta didik tentang jawaban mereka untuk tingkatan pertama dan kedua. Penelitian lain dilakukan oleh Alsagaf dan Wahyudi (2019) dengan judul Pengembangan Tes Diagnostik Three-Tier Multiple Choice untuk Mengukur Konsepsi Fisika Siswa SMA bahwa berdasarkan persentase yang didapat dari penelitian menunjukkan bahwa instrumen tes miskonsepsi berbentuk three-tier yang dikembangkan mampu mendeteksi miskonsepsi peserta didik untuk tiap indikatornya.

\section{KESIMPULAN}

Berdasarkan analisis data yang didapatkan dari penelitian tentang identifikasi miskonsepsi (conceptual misunderstandings atau pemahaman konseptual yang salah) menggunakan three-tier diagnostic test berbasis google form pada pokok bahasan potensil listrik dapat disimpulkan bahwa persentase rata-rata dari three - tier diagnostic test yang mengalami miskonsepsi yaitu $34 \%$, hal ini menunjukkan arti bahwa miskonsepsi berada pada kategori sedang. Indikator soal yang paling tinggi mengalami miskonsepsi yaitu pada soal 17-18 (menjelaskan energy yang tersimpan dalam medan magnet) dengan nilai $65 \%$.

\section{DAFTAR PUSTAKA}

Alsagaf, Syarif Lukman Hakim dan Wahyudi. 2019. Pengembangan Tes Diagnostik ThreeTier Multiple Choice untuk Mengukur Konsepsi Fisika Siswa SMA. Jurnal Pendidikan, 4(2): 47-54

Ariani, T. (2019). Perbedaan Hasil Belajar Fisika Menggunakan Model Pembelajaran Student Team Achievement Division (STAD) dan Model Pembelajaran Teams Games Tournament (TGT) Di SMP Negeri Air Lesing. Jurnal Sains dan Pendidikan Fisika, 14(2).

Astuti, B., Fitrianingrum, A. M., \& Sarwi, S. (2018). Penerapan Instrumen Three-Tier Test untuk Mengidentifikasi Miskonsepsi Siswa SMA pada Materi Keseimbangan Benda Tagar. Phenomenon: Jurnal Pendidikan MIPA, 7(2), 88-98.

Hasanah, Avisa. 2020. Pengembangan Instrumen Miskonsepsi Berbasis Google Forms Pada Materi Usaha dan Energi Menggunakan Four Tier Test . Lampung: UIN Raden Intan

Hasan,S.D., Bagayoko., \& Kelley, E.L (1999). Misconceptions and the Certainty of Response Index (CRI). Journalof Phys Educ.

Hashish, A. H., Seyd-Darwish, I., \& Tit, N. (2020). Addressing Some Physical Misconceptions in Electrostatics of Freshman Engineering Students. International Journal for Innovation Education and Research, 8(2), 01-07 
Iqbal. M., Simarmata. J., \& Feriyansyah. F. (2018). Using Google form for Student Worksheet as Learning Media. International Journal of Engineering \& Technology, 7 (3.4) $321-324$

Jumini, Sri, dkk. 2017. Identifikasi Miskonsepsi Fisika Menggunakan Three Tier Diagnostic Test pada Pokok Bahasan Kinematika Gerak. Wonosobo: Universitas Sains AlQuran

Karim. S., Saepuzaman. D., \& Sriyansyah. S.P (2015) Diagnosis Kesulitan Belajar Mahasiswa Dalam Memahami Konsep Momentum. Jurnal penelitian \& pengembangan pendidikan fisika. Vol 1 no 1 hal 85

Maryam, E., \& Fahrudin, A. (2020). Pengembangan Sound Card Laptop sebagai Alat Praktikum Fisika untuk Penentuan Percepatan Gravitasi Bumi. Silampari Jurnal Pendidikan Ilmu Fisika, 2(1), 29-40.

Mosik \& Maulana. P.(2010). Usaha Mengurangi Terjadinya Miskonsepsi Fisika Melalui Pembelajaran Dengan Pendekatan Konflik Kognitif . Jurnal Pendidikan Fisika Indonesia. Vol 6 hal 98-103.

Nurhayati, N., Al Sagaf, S. L. H., \& Wahyudi, W. (2020). PENGEMBANGAN TES DIAGNOSTIK THREE-TIER MULTIPLE CHOICE UNTUK MENGUKUR KONSEPSI FISIKA SISWA SMA. JP (Jurnal Pendidikan): Teori dan Praktik, 4(2), 47-54.

Nurulwati., Veloo \& Ali. R. M.(2014) Suatu Tinjauan Tentang Jenis-Jenis Dan Penyebab Miskonsepsi Fisika. Jurnal Pendidikan Sains Indonesia, Vol. 02, No.01, hlm 87-95

Rachmawati . Y., Maarif. M., Fadillah. N., Inayah. N., Ummah. K., Siregar. N.M.F., Amalianingsih. R., Aftanalia. F., Auliyah.A. (2020) Studi Eksplorasi Pembelajaran Pendidikan IPA Saat Masa Pandemi COVID-19 di UIN Sunan Ampel Surabaya. Indonesian Journal of Science Learning. Vol 1 (1) (2020) 32-36

Suhermiati, I. (2015). Analisis Miskonsepsi Siswa pada Materi Pokok Sintesis Protein Ditinjau dari Hasil Belajar Biologi Siswa. BioEdu, 4(3).

Sulistiyono, S. (2020). EFEKTIVITAS MODEL PEMBELAJARAN INKUIRI TERBIMBING TERHADAP KETERAMPILAN PROSES SAINS DAN PEMAHAMAN KONSEP FISIKA SISWA MA RIYADHUS SOLIHIN. Jurnal Pendidikan Fisika Undiksha, 10(2), 61-73.

Sheftyawan, W. B., Prihandono, T., \& Lesmono, A. D. (2018). Identifikasi Miskonsepsi Siswa Menggunakan Four-Tier Diagnostic Testpada Materi Optik Geometri. Jurnal Pembelajaran Fisika, 7(2), 147-153

Taufiq, M. (2012) Remediasi Miskonsepsi Mahasiswa Calon Guru Fisika Pada Konsep Gaya Melalui Penerapan Model Siklus Belajar (Learning Cycle) 5E. Jurnal Pendidikan IPA Indonesia. Vol 1 (2) hAl 198-203

Verkade, H., Mulhern, T. D., Lodge, J., Elliott, K., Cropper, S., Rubinstein, B., ... Dooley, L. (2017). Misconceptions as a Trigger For Enhancing Student Learning in Higher Education. The University of Melbourne: Melbourne.

Zakiya, Z., Amin, A., \& Lovisia, E. (2019). PENERAPAN METODE EKSPERIMEN PADA PEMBELAJARAN FISIKA SISWA KELAS X SMAN 3 LUBUKLINGGAU TAHUN PELAJARAN 2018/2019. SILAMPARI JURNAL PENDIDIKAN ILMU FISIKA, 1(2), 130-138.

Puplished at https://ojs.stkippgri-lubuklinggau.ac.id/index.php/SJPIF 